\title{
The sociological Imagination and Media Studies in Neoliberal Times
}

\author{
Shani Orgad
}

\begin{abstract}
Over the last two decades, Television and New Media has provided a vital platform to explore the importance of media texts, technologies, institutions, practices and processes for normalizing inequality and injustice. One of the critical themes within this agenda, on which much of my own work has focused, concerns the role of narratives in sustaining relations of power and inequality. However, to date, media and communications studies mostly examine narratives either as stories that circulate in public discourse or as people's personal narratives. In the context of deepening inequalities, the cementing of neoliberal rationality and the intensifying centrality of media and communication technologies in public and everyday life, connecting the two realms is a vital task.

Drawing on C. Wright Mills' The Sociological Imagination, I argue for and demonstrate the value of connecting what Mills famously called "the personal troubles of milieu" and "the public issues of social structure" in the study of current media and narrative. Analysis of how contemporary social and cultural narratives furnish and condition our most intimate personal troubles has a tragic aspect; that is, the realization that our lives are shaped by social forces not of our own making. Yet the intersection between media and cultural discourses and individuals' sense-making of their experiences can open up possibilities for change and even resistance. Indeed, studying the relationship between social narratives and people's personal narratives offers a way to link our understanding of social change to the critical media analysis which Television and New Media has been known for since the turn of the century.
\end{abstract}


Over the last twenty years, Television \& New Media has provided a vital platform for critical exploration of the role of media texts, technologies, institutions, practices and processes in normalizing, perpetuating, reinforcing and masking inequality and injustice. Reading this critical and challenging work often leaves me deeply alarmed and concerned. At the same time, much of the work published in TVNM provides crucial space for hope and instructive thinking about how inequality and injustice are and can be disrupted, resisted and challenged in an increasingly mediated, networked and corporatized world.

In this short article, I focus on a critical theme in this agenda and a preoccupation of much of my own work, namely the role of narratives for sustaining, negotiating and resisting relations of power and inequality. I first discuss (inevitably briefly) how, to date, media and communication studies has examined narratives as either stories that circulate in public discourse (media representations) or as people's personal narratives. I then argue that connecting the two realms-cultural and media narratives and personal narratives-is crucial for critical scholarship in current media and communications. Drawing on and thinking in line with C. Wright Mills' (1959) The Sociological Imagination, I sketch a broad framework for undertaking this task.

\section{Cultural narratives and Personal Narratives: Mind the Gap}

Since the turn of the century, a wealth of important research has emerged-a great deal of it discussed on the pages of TVNM - about the complex and often alarming ways in which gender, sexual, racial and class inequalities are reinforced, naturalized and silenced symbolically in a variety of television and other media texts (e.g., Ault 2013; Bradfield 2012; Cobb 2018; Drew 2011; Esposito 2009). This important body of 
scholarship underscores how media and cultural discourses construct, legitimize, naturalize and normalize neoliberal values, ideas and subject positions. This critical research, especially feminist studies influenced by Foucault's 'archeological' work, highlights the efficacy of the disciplinary power of contemporary media discourses and the powerful ways in which they privatize public issues and social uncertainties, making them a matter of individual responsibility. These studies examine and demonstrate how cultural and media narratives disavow and evacuate collective language, structural explanations and concerns over justice, replacing them with individualized and psychologized modes of thinking, feeling and being in the world (e.g. Banet-Weiser 2018; Gill 2017; Gill and Orgad 2015; Leonard 2018; Littler; Negra and Tasker 2014; Rottenberg 2018). ${ }^{\mathrm{i}}$

However, as Stuart Hall $(1996,12)$ argues in his influential theorization of identity (critiquing Foucault's earlier work), "it is not enough for the Law to summon, discipline, produce and regulate, but there must be the corresponding production of response...from the side of the subject." Our analysis of discursive and disciplinary regulation, Hall contends, must be complemented with an account of the psychic mechanisms and interior processes through which subjects attach, or negotiate, resist and fail to attach to the subject positions constructed by public discourses. That "side of the subject" has been the focus of important sociological studies which highlight how neoliberalism is experienced as a "lived system of meanings and values in the emotional sphere" (Silva, 2013, 98; see, e.g. Illouz 2007; Sennett 1998), or what Scharff (2016) and Gill (2017) call, respectively, the affective and psychic life of neoliberalism. However, empirically, to date, sociological studies have said little about how individuals' lived experience of neoliberalism and inequality connect (or not) to the media and cultural discourses within which their experience is situated. In other words, the relationship 
between the rich analysis of how contemporary cultural and media narratives and technologies construct and normalize inequalities and power relations in neoliberalism, and how people experience, negotiate and cope with these inequalities in their everyday lives, has remained largely unexplored (for a similar observation regarding the subfield of feminist media studies, see Grindstaff and Press 2014). However, as I argue in the next section, investigating this relationship is an ever more urgent task.

\section{The sociological Imagination, Media Studies and Narrative}

Sixty years ago, the American sociologist C. Wright Mills published the foundational text The Sociological Imagination. The value of sociology, Mills contended, lies in its capacity to make connections between what he called "personal troubles" and "public issues." Writing during the post-war period when "older ways of feeling and thinking have collapsed" and where people felt they could not cope with the larger world with which they were confronted (Mills 1959,4), Mills argued that the task of the social sciences is to identify the larger social forces that furnish our most intimate personal troubles. Every social study, he wrote, should connect the "personal troubles" of private individuals to "public issues" of history and society, in order to show both how we are produced as subjects and how we can be more than what we are already (Gane and Back 2012).

As Nicholas Gane and Les Back $(2012,7)$ argue, the sociological imagination is a critical sensibility that is ever more important today, precisely because the contemporary neoliberal world "seeks to tear asunder private troubles from public issues, and thereby turn social uncertainty into a personal failure that is divorced from any collective cause or remedy." Theirs is a sensibility that invites us to probe the relationship between 
public issues, which often are constructed as "big" meta, impersonal forces, over which we have little control, and the most intimate "small" personal troubles we experience in our everyday lives. Drawing on Gane and Back (2012), I suggest that, in the context of deepening inequalities, the cementing of neoliberal rationality and the intensifying centrality and ubiquity of media and communications technologies in public and everyday life, this sensibility is a vital resource for a critical media and communications scholarship. While the sociological imagination is a "quality of mind" (Mills 1959, 15) that informs and inspires different empirical and analytical approaches, in the space available here, I want to focus on one such approach, namely the study of how individuals' self-narratives connect to broader cultural and media narratives.

Public issues are formed, articulated and organized in and through narratives, which, in turn, provide individuals with resources to configure their "personal troubles" and make sense of the way they live and how they want to live. Identities "arise from the narrativization of the self" (Hall 1996, 4) and, especially today, when this storytelling occurs increasingly on public mediated platforms, it has the potential to feed into and shape the "bigger" stories of society. Narratives—both personal and cultural—are key sites through which inequalities and injustice are articulated, sustained reproduced and normalized, but, also, where injustice can be disrupted, resisted and subverted. Thus, examining the connections and disjunctures between the realms of people's personal and private stories of their experience and cultural and media narratives, offers a framework for understanding how social narratives furnish and condition our most intimate personal experiences and, crucially, how we might be able to negotiate, challenge and change these narratives. 
I would like briefly to illustrate how I have developed and used this approach in my own work. In my first book, Storytelling Online: Talking Breast Cancer on the Internet (Orgad 2005), I demonstrated how women work through their experience of breast cancer by appropriating, negotiating and responding to wider cultural narratives of breast cancer and of health and illness more broadly. Drawing on discourse analyses of cultural narratives of breast cancer and illness in online forums and personal journals (the precursors to blogs) and on in-depth interviews with breast cancer patients, I highlighted how the personal stories women produced online and offline, were deeply entwined with prevalent cultural and social narratives of self-responsibility, triumphalism and the privatization of illness. Their personal narratives were profoundly marked by, but concurrently resisted the dominant self-help narrative and the subject position of the survivor (Orgad 2009). Connecting these women's personal narratives and the broader cultural narratives within which their experience is situated, revealed how the stories they publish online empower them while, at the same time, contouring their experience within a therapeutic narrative of self-help and selfresponsibility. The prevalent self-help narrative disavows suffering, despair and anger and deflects attention away from structural issues that shape and affect their experiences of illness and health.

In my most recent book, Heading Home: Motherhood, Work and the Failed Promise of Equality (Orgad 2019), I juxtapose the personal narratives of women who left professional careers after having children and cultural and media narratives of women, work and family within which their personal accounts and experience are situated (see also Orgad 2016, 2017). I discuss how women's personal experiences of combining professional careers in toxic work cultures with motherhood were profoundly shaped by the work-life balance fantasy and the disciplinary figure of the "balanced woman" 
(Rottenberg 2018), and by contradictory narratives of motherhood circulating in contemporary culture. Similarly, I show how women's personal hopes for their imagined future trajectories draw on and respond to broader media narratives about the promise of the gig economy and specifically, self-employment, control, flexibility, self-fulfillment, satisfaction and pride.

My analysis highlights how even the educated and privileged women I interviewed, who are able to identify some of the social forces of inequality that had determined their decision to leave paid employment, repeatedly linked quitting their jobs to personal failure, whose source and remedy lay in the self. In the absence of social structural arrangements that support families and work cultures compatible with family life and, in the absence of narratives of collective action, solidarity, community and justice, these women reverted to individualized accounts of empowerment, confidence, grit and resilience as a way to make sense of their lives. Similarly, Christina Scharff (forthcoming) shows powerfully how the young educated women she interviewed about their experience of inequality at work provided incisive accounts of persisting gendered hierarchies while they at the same time lacked the vocabulary and means to translate their private troubles into public issues and collective action.

\section{Conclusion}

Exploring how contemporary social and cultural narratives furnish and condition our most intimate personal troubles has a tragic aspect: the realization that our lives are shaped deeply by social forces not of our own making and that our identities are constituted and limited by the discourses available to us (see also Gitlin 2000). However, connecting media and cultural discourses and individuals' sense-making of 
their experiences can open possibilities for change and even resistance. Their connection holds "the political promise of helping individuals better understand and control the larger structural forces hat shape[d] their lives" (Geary 2009, 177, cited in Gane and Back 2012,11). Understanding why and how individuals invest in and seize on certain discourses, cultural scripts and fantasies is critical for understanding "what might in any way interrupt, prevent or disturb" this investment and the "smooth insertion of individuals into the subject positions constructed by [...] discourse" (Hall 1996, 11). By drawing connections between media and cultural narratives and people's personal narratives of their experience, critical scholarship can help us recognize that personal troubles are not just private problems that have no name-as Betty Friedan (1963) put it more than half a century ago-and prompt us to look for social and structural ways to tackle these "private troubles." ${ }^{i i}$ Indeed, studying the relationship between "private troubles" and "public issues" offers a way to link our understanding of social change to the critical media analysis for which TVNM has been a key space for the last twenty years. 


\section{References}

Ault, Elizabeth. 2013. "You Can Help Yourself/but Don't Take Too Much” African American Motherhood on The Wire." Television \& New Media 14 (5): 386-401.

Banet-Weiser, Sarah. 2018. Empowered: Popular Feminism, Popular Misogyny and the Economy of Visibility. Durham: Duke University Press.

Bradfield, Shelley-Jean. 2013. "Madam \&Eve: The Politics of Race and Postcolonial Television in South Africa." Television \& New Media 14 (6): 529-545.

Cobb, Shelley. 2018. “'I'd Like Y'all to Get a Black Friend': The Politics of Race in Friends." Television \& New Media 19 (8): 708-723

Drew, Emily, M. 2011. “Pretending to be 'Postracial': The Spectacularization of Race in Reality TV's Survivor." Television \& New Media 12 (4): 326-346.

Esposito, Jennifer. 2009. "What Does Race Have to Do with Ugly Betty?: An Analysis of Privilege and Postracial(?) Representations on a Television Sitcom." Television \& New Media 10 (6): 521-535.

Friedan, Betty. 2000 [1963]. The Feminine Mystique. London: Penguin.

Gane, Nicholas and Back, Les. 2012. “C. Wright Mills 50 Years On: The Promise and Craft of Sociology Revisited." Theory, Culture \& Society 29 (7-8): 1-23.

Geary, Daniel. 2009. Radical Ambition: C. Wright Mills, the Left, and American Social Thought. Berkley: University of California Press.

Gill, Rosalind. 2017. "The affective, cultural and psychic life of postfeminism: A postfeminist sensibility 10 years on." European Journal of Cultural Studies 20 (6): 606626. 
Gill, Rosalind and Orgad, Shani. 2015. "The Confidence Cult(ure)." Australian Feminist 30 (86): 324-344.

Gitlin, Todd. 2000. “Afterword.” In The Sociological Imagination, by Charles Wright Mills, 229-242. Oxford: Oxford University Press.

Grindstaff, Laura and Andrea Press 2014. "Too Little But Not Too Late: Sociological Contributions to Feminist Studies." In Media Sociology, ed. S. Waisbord, 151-167. Cambridge: Polity.

Hall, Stuart. 1996. “Introduction: Who Needs Identity?” In Questions of Cultural Identity, edited by S. Hall and du Gay, P. 1-17. London: Sage.

Illouz, Eva. 2007. Cold Intimacies: The Making of Emotional Capitalism. Cambridge: Polity.

Leonard, Suzanne. 2018. Wife, Inc.: The Business of Marriage in the Twenty-First Century. New York: New York University Press.

Littler, Jo. 2018. Against Meritocracy: Culture, Power and Myths of Mobility. London: Routledge.

Livingstone, Sonia. 2019. "Audiences in an Age of Datafication: Critical Questions for Media Research." Television \& New Media, 20(2): 170-183.

Mills, Charles Wright. 1959. The Sociological Imagination. Oxford: Oxford University Press.

Orgad, Shani. 2005. Storytelling Online: Talking Breast Cancer on the Internet. New York: Peter Lang. 
Orgad, Shani. 2009. "The Survivor in contemporary culture and public discourse: A genealogy." The Communication Review, 12(2): 132-161.

Orgad, Shani. 2016. “Incongruous Encounters: Media Representations and Lived Experiences of Stay-at-home Mothers." Feminist Media Studies, 16(3): 478-494.

Orgad, S. 2017. "The Good Wife: The fantastic working mother on the fantastical treadmill." Television \& New Media, 18(2): 165-183.

Orgad, Shani. 2019. Heading Home: Motherhood, Work and the Failed Promise of Equality. New York: Columbia University Press.

Rottenberg, Catherine. 2018. The Rise of Neoliberal Feminism. Oxford: Oxford University Press.

Scharff, Christina. 2016. "The psychic life of neoliberalism: Mapping the contours of entrepreneurial subjectivity." Theory, Culture \& Society, 33(6): 107-122.

Scharff, Christina. Forthcoming. “From 'not me' to 'me too': exploring the trickle-down effects of neoliberal feminism." Rassegna Italiana di Sociologia, special issue on "Feminism: Historical Legacies and Current Challenges."

Sennett, Richard. 1998. The Corrosion of Character: The Personal Consequences of Work in the New Capitalism. New York: Norton.

Silva, Jennifer. 2013. Coming Up Short: Working-Class Adulthood in an Age of Uncertainty. Oxford: Oxford University Press.

Negra, Diane and Tasker, Yvonne. 2014. Gendering the Recession: Media and Culture in an Age of Austerity. Durham: Duke University Press. 


\section{Notes}

i Another critical strand of research which I do not have the space to discuss here examines the experiences of work, and particularly digital labour, in the neoliberal work cultures of the cultural and creative spheres.

ii Gane and Back note the Millsian quality of Friedan's The Feminine Mystique while Livingstone (2019) has recently made a related argument about the importance of accounting for and connecting the study of audiences' relation to the everyday lifeworlds and the public worlds of citizen action, through the study of metaprocesses such as mediatization and datafication. 